\title{
O PODER DOS DISCURSOS HISTÓRICOS
}

Cleverton Barros de Lima

UNICAMP/ FAPESP

E-mail: cleverton.lima@gmail.com

ADDIS, Ferdie. Discursos que mudaram a história. Tradução Thaïs Costa. Org. Nicolau Sevcenko, São Paulo: Prumo, 2012.

Um discurso bem articulado revela o bom preparo no manejo das regras da argumentação. As ferramentas do convencimento são assim acionadas para persuadir o interlocutor, como lembra Chaim Perelman (2005). Cabe ainda ao ator do discurso, preocupar-se em obter uma "uma larga audiência"; e que esta, o tratem como parte de uma comunidade. Estes são os requisitos de uma tradição que remonta ao período histórico da Grécia antiga, onde os oradores convenciam seus interlocutores pelo uso do convencimento delimitado nos debates. Hannah Arendt realçou essa peculiaridade, ao afirmar que, esta comunidade não estava orientada pela violência, mas por uma clara confiança no poder do discurso. Talvez, seja um dos problemas da contemporaneidade repensar a convivência dos membros da comunidade, sem o uso "mudo" da violência, mas consagrando o discurso como ferramenta política propulsora das mudanças no tecido social e político.

Daí a relevância de pensar os discursos nos debates políticos na contemporaneidade, como parte central do jogo político. Desde o uso da palavra para a "banalização do mal", (penso aqui nas reflexões de Hannah Arendt) e de uma retórica dominadora e perversa por Adolf Hitler durante a Segunda Guerra; até a defesa dos recursos do meio ambiente, proferido por Marina Silva no início desse século, essas são algumas das referências do livro Discursos que mudaram a História. O leitor terá acesso ao discurso pronunciado pelo pastor Martin Luther King Jr. na luta pelos direitos civis, que definitivamente, realça o papel imprescindível desse gênero literário como fonte histórica.

É justamente sobre a narrativa discursiva, o tema central da antologia "Discursos que mudaram a História”. Originalmente publicado em 2011, com o título I Have A Dream: The

Oficina do Historiador, Porto Alegre, EDIPUCRS, v. 7, n. 2, jul./dez. 2014, p. 243-246. 
Speeches That Changed History, o texto agora está à disposição do público, nesta obra coligida por Ferdie Addis. Eles são abordados enquanto marca privilegiada das mudanças sociais que originaram, a exemplo do discurso que intitula a obra na versão original, reconfigurações políticas de impacto nas relações sociais.

Ferdie Addis é britânico e obteve uma formação clássica, em latim e grego, pela Universidade de Oxford. Sua experiência com o campo da história está difundida na pesquisa para documentários televisivos, ao mesmo tempo em que escreveu e publicou obras sobre a compreensão do mundo antigo, como os estudos voltados à historicização da mitologia grega no recém-publicado no Brasil, A caixa de Pandora (2012). Numa vertente antológica empregada no livro Discursos históricos, Addis publicou em 2013, Amen to That!: The Amazing Way the Bible Influences Our Everyday Language; neste livro, o autor faz uma análise das expressões linguísticas que estão relacionadas aos escritos bíblicos, numa acepção que dialoga com a ideia de Northrop Frye, de que a Bíblia é "o código dos códigos" (2004). Portanto, Ferdie Addis compromete-se em comunicar ao ciclo acadêmico, mas não se abstém de escrever para o grande público, interesses candentes tratados na universidade.

Além de Addis, O livro Discursos que mudaram a história tem na edição brasileira, a assinatura na organização de Nicolau Sevcenko. O historiador brasileiro é conhecido por livros que marcaram a historiografia, como Orfeu extático na metrópole (1992) e a Literatura como Missão: Tensões sociais e criação cultural na Primeira República (2003). Atualmente, Sevcenko é professor do departamento Romance languages and literatures da Universidade de Harvard e titular do departamento de história da Universidade de São Paulo (USP).

A obra está dividida numa "longa duração" cronológica que englobam desde os "Oradores clássicos", o clássico "O sermão da Montanha de Jesus Cristo" e "Sermões de Padre Antônio Vieira", a textos atuais, como o "Discurso da Vitória do presidente Barack Obama" e por fim, o memorável discurso de Marina Silva, "Em Defesa do Meio Ambiente". No total, a antologia abrange em maior número, discursos do século vinte, o que evidencia o valor desse tipo de referência da política no tempo presente.

Os "sofistas" foram os primeiros a organizar a retórica de forma codificada. Esses mestres do discurso contavam com a audiência dos jovens gregos da aristocracia que almejavam aprender a essência da argumentação. Todavia, coube a Aristóteles, pensador grego, consagrar a utilização de forma metódica, do discurso em sua obra. A arte da retórica, assim, delimitou a exigência do bem falar em público, como requisito indispensável da formação educacional. Justificadamente, a coletânea traz trechos dos discursos de Homero, na

Oficina do Historiador, Porto Alegre, EDIPUCRS, v. 7, n. 2, jul./dez. 2014, p. 243-246. 
Ilíada; Péricles, com sua Oração fúnebre; Demostenes, a Terceira Filípica, e por último, do orador Cícero, com sua Décima terceira Filípica.

O que talvez gere uma estranheza é o enquadramento do "Sermão da Montanha", proferido por Jesus Cristo, como um discurso propriamente dito. Isto porque, na tradição cristã, os evangelhos trazem palavras ditas por Cristo, aos seus discípulos, demostrando a extensão de seu ensino. A escolha do texto é justificada pelos organizadores da obra, muito mais pelas mudanças que o sermão propagou em outros períodos históricos; isto é, por sua dimensão "verdadeiramente revolucionária" (ADDIS, 2012, p. 19). A adesão de milhares de pessoas à fé em Cristo abriu espaço para o imperador Constantino, o Grande, tornar o cristianismo, a religião oficial do Império Romano. E, ainda hoje, este segmento religioso é o de maior adesão no mundo, seguido pelo Islamismo.

A dinâmica de cada discurso no livro é bem interessante enquanto ferramenta didática. Primeiro, uma explicação geral, como no capítulo sobre Oliver Cromwell; a visibilidade desta figura foi construída quando o mesmo lutou ao lado do Partido Puritano, contra os partidários de Carlos I, entre 1642 a 1648. Período histórico trabalhado por Christopher Hill, no clássico O mundo de ponta-cabeça, onde descreve com maestria os resultados da Revolução Inglesa, quando Oliver Cromwell despontou à condição de líder político. Cromwell esperou a implantação de uma reforma religiosa, que na realidade nunca chegou, pois os membros do Parlamento Rump estavam satisfeitos em trabalhar pelo próprio bem-estar. Na sequência, o leitor tem acesso à segunda parte, ou seja, o discurso; neste tocante, o discurso Cromwell, é bem instigante para uma reflexão da crise institucional que o Parlamento inglês vivenciou naquela época. Por fim, os organizadores da coletânea, descrevem "as consequências" do discurso, como resultado da luta do líder puritano, para estancar a "corrupção da velha ordem parlamentar". O Parlamento Rump fora dissolvido, e o grupo de protestantes liderados por Cromwell não conseguiram êxito em governar a Inglaterra. Após a morte do líder puritano, em 1658, a monarquia retomou ao poder com o rei Carlos II. Monarquia que persiste inabalável até hoje.

Enfim, o livro de Addis suscita uma aproximação do papel dos discursos, naquilo que Hannah Arendt denominou como parte essencial da condição humana. Isto porque, o discurso está relacionado à ação, que "é prerrogativa exclusiva do homem", como diz a pensadora (ARENDT, 2008, p.35). Ao se referir ao discurso como parte da condição humana, somente a ação e o discurso são claramente identificáveis como político. Daí a valor dos discursos, pois trazem os elementos aos quais é indispensável à filósofa, qual seja, utilizá-los na condição de

Oficina do Historiador, Porto Alegre, EDIPUCRS, v. 7, n. 2, jul./dez. 2014, p. 243-246. 
instrumento de decisão mediante o uso de palavras e persuasão, relegando, assim, a força da violência como ato não político. Por isso, a urgência de refletir as implicações de um discurso que tragam o agente das mudanças políticas utópicas. Esse elemento é o ponto fulcral de uma coletânea que se serve da ideia, não só da tessitura dos discursos, mas, sobretudo, de suas consequências, ápice da condição humana da ação na história.

\section{REFERÊNCIAS BIBLIOGRÁFICAS}

ARENDT, Hannah. A Condição humana. Trad. Roberto Raposo, São Paulo: Editora Forense, 2008.

ADDIS, Ferdie. A Caixa de Pandora. As curiosas histórias da mitologia por trás de expressões do nosso dia a dia. Trad. Pedro Sette-Câmara. Rio de Janeiro: Casa da Palavra, 2012.

ADDIS, Ferdie. Amen to That!: The Amazing Way the Bible Influences Our Everyday Language. New York: Readers Digest, 2013.

FRYE, Northrop. O Código dos códigos: a Bíblia e a literatura. Trad. Flávio Aguiar. São Paulo: Boitempo, 2004.

HILL, Christopher. $O$ mundo de ponta-cabeça: ideias radicais durante a revolução inglesa de 1640. Trad. Renato Janine Ribeiro. São Paulo: Companhia das Letras, 1987.

PERELMAN, Chaim. Tratado da argumentação: a nova retórica. Trad. Maria Ermantina de Almeida Prado Galvão. São Paulo: Martins Fontes, 2005.

SEVCENKO, Nicolau. Orfeu extático na metrópole - São Paulo, sociedade e cultura nos frementes anos 20. São Paulo: Companhia das Letras, 1992.

SEVCENKO, Nicolau. Literatura como missão - Tensões sociais e criação cultural na Primeira República. São Paulo: Companhia das Letras, 2003.

RESENHA ENVIADA EM: 27/10/2014

ACEITA PARA PUBLICAÇÃO EM: 07/11/2014

Oficina do Historiador, Porto Alegre, EDIPUCRS, v. 7, n. 2, jul./dez. 2014, p. 243-246. 